\title{
STIMULATION OF GONADOTROPHIN SECRETION WITH THE PREGNANCY INHIBITOR D-6-METHYL-8-CYANOMETHYLERGOLINE (I)
}

\author{
M. ŠEDA, K. ̌̌EŽÁBEK, O. MARHAN AND M. SEMONSKY̌ \\ Research Institute of Pharmacy and Biochemistry, Prague 3, Czechoslovakia
}

(Received 19th May 1970)

D-6-Methyl-8-cyanomethylergoline (I) (compound 6605 VÚFB) prevents pregnancy in rats when given orally up to the 7th day after copulation (Režábek, Semonský \& Kucharczyk, 1969). A similar effect was seen with the chemically related compounds, ergocristine, ergocryptine, ergocornine, ergosine and ergovaline (Shelesnyak, 1957; Kraicer \& Shelesnyak, 1965). All the evidence shows that these drugs interfere with the secretion of hypophysial luteotrophic hormone ( $\mathbf{L t H})$, which is necessary for the correct function of corpora lutea (Shelesnyak, 1957; Zeilmaker \& Carlsen, 1962; Lindner \& Shelesnyak, 1967). Moreover, Lobel, Shelesnyak \& Tic (1966) observed histological changes in the ovary associated with a drop in the levels of LtH and a rise in FSH and LH after ergocornine. This indicated that ergocornine might have a direct or indirect influence on the secretion of hypophysial gonadotrophins.

Since the action of compound 6605 VUFB on pregnancy appears to resemble that of ergocornine, we decided to study the effects of the compound on the increase in the secretion of gonadotrophins which takes place after unilateral ovariectomy in rats. (Peterson, Edgren \& Jones, 1964; Benson, Sorrentino \& Evans, 1969). We also considered the possible interaction of compound 6605 VUFB with methallibure (ICI 33828), which is known to inhibit gonadotrophin secretion (Paget, Walpole \& Richardson, 1961).

Adult, nulliparous, female rats of the Wistar Konárovice strain, weighing 160 to $180 \mathrm{~g}$, were allocated to five groups. Group 1 consisted of intact animals. Groups 2 to 5 consisted of animals which were unilaterally ovariectomized (left ovary removed) under light ether anaesthesia on the lst experimental day. The animals of both control groups ( 1 and 2) received $1 \mathrm{ml}$ of physiological saline. The animals of Group 3 received $0.5 \mathrm{mg}$, and those of Group $4,1.0 \mathrm{mg}$ of compound 6605 VÚFB. The rats in Group 5, received $12 \mathrm{mg}$ of methallibure, followed $20 \mathrm{~min}$ later by $1.0 \mathrm{mg}$ of compound 6605 VÚFB. These doses were administered by gavage once a day for 12 days, beginning on the day of unilateral ovariectomy. The daily doses of 6605 VÚFB were each dissolved in $1 \mathrm{ml}$ of water and the dose of methallibure was suspended in $0.5 \mathrm{ml}$ of vehicle SV 17874 (Dorfman, 1962). On the day following the twelfth dose, the animals were killed by cervical dislocation, the remaining ovary was extirpated, freed from adherent tissue and weighed on a torsion balance.

The left-sided ovariectomy resulted in hypertrophy of $47 \%$ of the remaining 
right ovary. Compound 6605 VÚFB increased this hypertrophy, the dose of $1 \mathrm{mg}$ being significantly more potent than the dose of $0.5 \mathrm{mg}$. When methallibure was added to the higher dose of compound $6605 \mathrm{VUFB}$, hypertrophy of the remaining ovary did not occur. The ovarian weight in this last group corresponded to that of the intact control group. Ovarian hypertrophy following unilateral ovariectomy has been attributed to the elevated secretion of gonadotrophins (Peterson et al., 1964; Benson et al., 1969). We used this technique because when using the specific OAAD assay (Parlow, 1958), we observed that, following administration of another structurally similar derivative, a drop in the hypophysial LH content occurred in accordance with the results of the abovementioned technique. We also observed a transient drop in hypophysial FSH content on the 4th day after unilateral ovariectomy when using Benson's modification of the Steelman \& Pohley assay method (Benson et al., 1969).

TABLE 1

THE EFFECT OF COMPOUND 6605 VÚFB AND METHALLIBURE ON THE WEIGHT OF THE RIGHT OVARY AFTER LEFT UNILATERAL OVARIEGTOMY

\begin{tabular}{|c|c|c|c|c|}
\hline Group* & Treatment & $\begin{array}{l}\text { Wt of right ovary } \\
\text { in } \mathrm{mg} \\
(\text { Mean } \pm \text { S.E. })\end{array}$ & $\begin{array}{l}\text { Wt of ovary } \\
\text { related to that } \\
\text { of intact control }\end{array}$ & $\begin{array}{l}\text { Significantly different } \\
\text { from the groups } \\
(P=0.01)\end{array}$ \\
\hline $\begin{array}{c}1 \\
(20)\end{array}$ & $\begin{array}{l}\text { Intact controls } \\
\quad 12 \times 1 \mathrm{ml} \text { physiol. saline }\end{array}$ & $25 \cdot 3 \pm 0.8$ & $100 \%$ & $2,3,4$ \\
\hline$\stackrel{2}{20}$ & $\begin{array}{l}\text { Unilateral ovariectomy } \\
12 \times 1 \mathrm{ml} \text { physiol. saline }\end{array}$ & $37 \cdot 2 \pm 1 \cdot 1$ & $147 \%$ & $1,3,4,5$ \\
\hline$\stackrel{3}{(20)}$ & $\begin{array}{l}\text { Unilateral ovariectomy } \\
12 \times 0.5 \mathrm{mg} 6605 \text { VÚFB }\end{array}$ & $46 \cdot 4 \pm 1 \cdot 6$ & $183 \%$ & $1,2,4,5$ \\
\hline $\begin{array}{c}4 \\
(17)\end{array}$ & $\begin{array}{l}\text { Unilateral ovariectomy } \\
12 \times 1.0 \mathrm{mg} 6605 \text { VÚFB }\end{array}$ & $54 \cdot 6 \pm 1 \cdot 6$ & $215 \%$ & $1,2,3,5$ \\
\hline $\begin{array}{c}5 \\
(10)\end{array}$ & $\begin{array}{l}\text { Unilateral ovariectomy } \\
12 \times 1.0 \mathrm{mg} 6605 \text { VÚFB } \\
12 \times 12 \mathrm{mg} \text { methallibure }\end{array}$ & $23 \cdot 4 \pm 1 \cdot 6$ & $92 \%$ & $2,3,4$ \\
\hline
\end{tabular}

* No. of animals in parentheses.

The results of the present study indicate that compound 6605 VÜFB stimulates the secretion of hypophysial gonadotrophins. The inhibition of this effect by the previous administration of methallibure is in agreement with its known blocking action.

Unpublished observations show that compound 6605 VÜFB blocks the secretion of prolactin. The stimulation of hypophysial gonadotrophins of $\mathrm{LH}$ and FSH type and simultaneous inhibition of prolactin could hardly be explained by direct action on the hypophysis. It is more logical to assume that the compound stimulates the hypothalamus to release $\mathbf{L H}$ and FSH-releasing and prolactininhibiting factors. Our results seem to support the hypothesis of Lindner \& Shelesnyak (1967), who suggested that the hypothalamus was responsible for the disturbed function of the hypophysis following the administration of ergocornine. The possibility of a stimulatory action of ergocornine on the hypothalamic secretion of prolactin-inhibiting factor was recently mentioned by Carpent \& Desclin (1969). 


\section{REFERENGES}

Benson, B., SorRentino, S. \& Evans, J. S. (1969) Increase in serum FSH following unilateral ovariectomy in the rat. Endocrinology, 84, 369.

Carpent, G. \& Desclin, L. (1969) Effects of ergocornine on the mechanism of gestation and on fetal morphology in the rat. Endocrinology, 84, 315.

Dorfman, R. I. (1962) Standard methods adopted by official organizations. In: Methods in Hormone Research, Vol. II, Bioassay, p. 709. Ed. R. I. Dorfman. Academic Press, New York.

KRaIcer, F. P. \& Shelesnyak, M. C. (1965) Studies on the mechanism of nidation. XIII. F. Reprod. Fert. 10, 221.

LiNDNER, H. R. \& SHELESNYAK, M. C. (1967) Effect of ergocornine on ovarian synthesis of progesterone and 20- $\alpha$-hydroxy-pregn-4-en-3-one in the pseudopregnant rat. Acta endocr., Copenh. 56, 27.

Lobel, B. L., Shelesnyak, M. C. \& Tic, L. (1966) Studies on the mechanism of nidation. XIX. 7. Reprod. Fert. 11, 339.

Paget, G. E., Walpole, A. L. \& Righardson, D. N. (1961) Non-steroid inhibitors of pituitary gonadotrophic function. Nature, Lond. 192, 1191.

Parlow, A. F. (1958) A rapid bioassay method for $\mathbf{L H}$ and factors stimulating LH secretion. Fedn Proc. Fedn Am. Socs exp. Biol. 17, 402.

Peterson, D. L., Edgren, R. A. \& Jones, R. C. (1964) Steroid-induced block of ovarian compensatory hypertrophy in hemicastrated female rats. F. Endocr. 29, 255.

ŘžABEK, K., SEMONSKÝ, M. \& KuCHARCZYK, N. (1969) Suppression of conception with D-6-methyl-8cyanomethylergoline (I). Nature, Lond. 221, 666 .

ShelesNYAK, M. C. (1957) Some experimental studies on the mechanism of ova implantation in the rat. Recent Prog. Horm. Res. 13, 269.

Zetlmaker, G. H. \& Garlsen, R. A. (1962) Experimental studies on the effect of ergocornine methansulfonate on the luteotropic function of the rat pituitary gland. Acta endocr., Copenh. 41, 321. 